\title{
Effect of different levels of protein diets on growth performance and carcass yield of pateri male goat kids
}

\section{Shoaib Ahmed Pirzado ${ }^{1 *}$, Muhammad Zakria ${ }^{2}$, Mansoor Tariq ${ }^{3}$, Muhammad Haroon Baloch ${ }^{4}$, Dildar Hussain Kalhoro ${ }^{5}$ Imdad Hussain Laghari $^{2}$, Gulfam Ali Mughal ${ }^{4}$, Fahmida Parveen ${ }^{3}$ and Riaz Ahmed Lagari ${ }^{6}$}

1. Department of Animal Nutrition,Faculty of Animal Husbandry and Veterinary Sciences, Sindh Agriculture University, Tandojam-Pakistan

2. Department of Poultry Husbandry, Faculty of Animal Husbandry and Veterinary Sciences, Sindh Agriculture University, Tandojam-Pakistan

3. Department of Veterinary Pathology, Faculty of Animal Husbandry and Veterinary Sciences, Sindh Agriculture University, Tandojam-Pakistan

4. Department of Livestock Management, Faculty of Animal Husbandry and Veterinary Sciences, Sindh Agriculture University, Tandojam. -Pakistan

5. Department of Veterinary Microbiology, Faculty of Animal Husbandry and Veterinary Sciences, Sindh Agriculture University, Tandojam-Pakistan

6. Department of Veterinary Medicine, Faculty of Animal Husbandry and Veterinary Sciences, Sindh Agriculture University, Tandojam-Pakistan

*Corresponding author's email: dr.pirzado@gmail.com

Citation

Shoaib Ahmed Pirzado, Muhammad Zakria, Mansoor Tariq, Muhammad Haroon Baloch, Dildar Hussain Kalhoro, Imdad Hussain Laghari, Gulfam Ali Mughal, Fahmeeda Parveen and Riaz Ahmed Lagari. Effect of different levels of protein diets on growth performance and carcass yield of pateri male goat kidsPure and Applied Biology. Vol. 5, Issue 4, pp1200-1206. http://dx.doi.org/10.19045/bspab.2016.50144

\begin{tabular}{llll}
\hline \hline Received: 03/08/2016 & Revised: 13/10/2016 & Accepted: 15/10/2016 & Online First: 03/11/2016
\end{tabular}

Abstract

The aim of present study was to determine the proper crude protein level for the male Pateri kids. Twenty four male Pateri goat kids were selected with an initial weight $15.4 \pm 0.4 \mathrm{~kg}$ and randomly distributed in three supplemented diets with i.e.11.5 (A), 14.5 (B) and $16.5 \%$ (C) crude protein level. Dry matter intake, average daily gain, feed conversion ratio, total weight gain, carcass characters and digestibility were studied for 60 day's trial. Statistical analysis indicated that there was no significant effect $(\mathrm{P}>0.05)$ of protein levels on dry matter intake but, maximum daily dry matter intake was $707.9 \mathrm{~g}(11.5 \% \mathrm{CP}$ level). However, ADG, feed efficiency and total weight gain showed significant $(\mathrm{P}<0.05)$ effect, higher weight gain $22.04 \mathrm{~kg}$, average daily gain $110.6666 \mathrm{~g}$ and better feed efficiency 6.17 (16.5\% CP level) was recorded. Furthermore, there was no significant difference $(\mathrm{P}>0.05)$ of protein levels on carcass weight and dressing percentage but, numerical variations were recorded. There was significant $(\mathrm{P}<0.05)$ interaction of proteins on digestibility of crude protein and ether extract but no effect (P>0.05) on ADF and NDF was noted. Therefore, it was concluded from present results that $16.5 \%$ C.P level is beneficial for growth performance, carcass yield and digestibility.

Keywords: Crude protein; Male Pateri kids; Performance and digestibility 


\section{Introduction}

Goats have numerous breed which are distributed and reared in the different regions of the world for their high demanding consumption of meat [1]. The production potential and efficiency of goats are very low in many countries of the world in primary and post production systems [2]. The meat of goat is also called chevon and it contain less muscular fat and more muscle shear power [3]. Goat meat is healthier and contains less fat than beef and sheep meat (mutton) for that reason human like and consume goat meat [4]. Pateri goats are mostly found in Sindh provinces. Especially poor peoples raised for milk and meat purpose. For the occasion of Eid-ul-Uzza Pateri male kids are raised by rural peoples for fattening purpose and then generate income through their sale.

Protein is very much important nutrient for the fattening animals; the ration should be formulated on the basis of dry matter and crude protein levels. When protein taken by animals they digested and absorbed by the rumen and then converted into amino acids which are necessary for the normal growth and development of muscles [5]. The proper ratios of protein supply to the ruminant animals to increase the growth and milk production, which is suitable for achieving more profit from livestock [6]. In general, protein is necessary for normal growth development for animals and the adequate amount of protein required for fattening purpose. Earlier research stated that ideal levels of crude protein in the ration are 14, 16 and 20.3 percent best for growth and fattening [7-9]. Out of all nutrients particularly protein has major advantage to increase the mutton production. Hence, usage of high levels of protein in the daily feeding allowances by the commercial farmers to achieve more growth rates [10]. Documentation on requirements of protein of Pakistani goats especially Pateri goat breed are very little information especially about crude protein to obtain good quality and more amount of mutton/meat by these kids in Pakistani environments. Therefore, the objective of this research work was to investigate effects of different $\mathrm{CP}$ levels on the growth and performance and carcass yield of Pateri male goat kids.

\section{Materials and methods}

The research trial was carried out for the period of 60 days at the livestock experimental station Sindh Agriculture University Tandojam. The feed samples of experimental diet were brought in animal nutrition laboratory for determination of chemical composition according to analytical methods of Association of Official Analytical Chemists [11].

A total 24 male of Pateri kids were allocated in three different groups $\mathrm{A}, \mathrm{B}$ and $\mathrm{C}$ for experimental purpose. Each group consists of 08 kids and their average age was about 04 months. The each kid was confined in separate pen for feeding and feces collection for recoding of feed intake and for digestibility during whole research trial. The ration was formulated on the basis of different levels of crude protein i.e. (11.5, 13.5 and $16.5 \mathrm{CP} \%$ ) according to experimental design. The formulation and chemical analysis of experimental diet are shown in Table 1. The experimental diet consists of berseem and concentrate. Before the starting of experimental period all kids were weighed and treated against internal and external parasites with Nilzan plus and Ivermectin. During the experiment feed offered 9:00 am and 5:00 pm daily, refusal feed was measure and subtracted from total feed for calculation of feed intake. Free choice supply of clean water to each kid thought out the experiment. The body weight of all kids were measured early in the morning before feeding. During the last week of experiment feces were collected and analyzed for determination of digestibility. 
The collected fecal samples were brought to Laboratory of Animal Nutrition for determination of proximate analysis for the digestibility. The protein was determined by the kjelldhal method, ether extract through the soxillet apparatus and crude fiber (ADF $\&$ NDF) by the method of Van Soest [12]. At the end of experiment 03 kids were slaughtered from each group for measure carcass weight the dressing percentage of meat. The following parameters were recorded during the entire period of study, dry matter intake, feed efficiency (FCR), weight gain, digestibility, carcass weight and dressing percentage. Obtained data were tabulated and analyzed by ANOVA and the means of different treatment were used for LSD at $5 \%$ level of significant through STATISTX, Version 8.1 (Copyright 2005, Analytical Software, USA).

Table 1. Feed ingredients and feed formulation for experimental animals

\begin{tabular}{|l|l|l|l|}
\hline Ingredients & A & B & C \\
\hline Cotton seed cake & 05 & 12 & 16 \\
\hline Maize & 20 & 25 & 20 \\
\hline Wheat bran & 15 & 12 & 20 \\
\hline Rice bran & 13 & 12 & 14 \\
\hline Rice crush & 22 & 18 & 07 \\
\hline Wheat crush & 11 & 10 & 08 \\
\hline Soybean & 00 & 02 & 06 \\
\hline Molasses & 10 & 05 & 05 \\
\hline Berseem & 04 & 04 & 04 \\
\hline Total & 100 & 100 & 100 \\
\hline Calculated DM and CP percentage & \multicolumn{2}{|l|}{} \\
\hline DM & 86.1 & 86.8 & 86.7 \\
\hline CP & $11.5 \%$ & $14.5 \%$ & $16.5 \%$ \\
\hline
\end{tabular}

\section{Results and discussion}

\section{Growth performance}

The influences of different levels of protein on growth performance are given in Table 2 . Statistical analysis revealed that there was no significant $(\mathrm{P}>0.5)$ effect of treatments on dry matter intake. In general, dry matter intake increased with crude protein level increased in the diet $[13,14]$. Present findings are in contrast with above researchers. These results are agreed with Ahn et al. [15] and Choi et al. [16] who noted that feed consumption was nonsignificant in sheep and Korean black goats with different crude protein ratio in their diet. These findings are accordance with the Prieto et al. [7] and Chobtang et al. [17] they observed that various ratios of protein in the diet did not affect significantly the dry matter intake in the Thai indigenous male goats, Spanish and Boer-Spanish crossbred kids. Same results were also detected by Zundit et al. [18] who noted no significant influence on feed intake with higher dietary C.P level in growing lambs. Rocha et al. [19], did not observed impact of protein levels $(14,16,18$, and $20 \% \mathrm{CP})$ on dry matter intake. However, ANOVA for the average daily gain and final body weight showed significant $(\mathrm{P}<0.05)$ difference among the treatments. These results showed that more protein level in diet results in better weight as compared with low protein ratio in the feed of goats. Shahjalal et al. [9], reported that diet with 16.9 and 20.35 crude protein in black Bengal goat results in more live weight gain with higher dietary protein $(20.3 \%)$. Protein plays important role in 
muscle development and is essential for growth of animals [20]. Mostly, animals in early growth more protein deposit in their body, which indicates that they can absorb diets with more protein ratio [21]. Jia et al. [22], reported that 16\% C.P level in Angora goat kids got more weight compared with other groups. Present findings are harmony with the results of Titti et al. [8], Choi et al. [16], and Wildeus et al. [23] who reported that increased level of crude protein in goat diet results in more weight gain. Negesse et al. [24], reported that more average daily gain in Saanen kids with higher protein ratio $(17.6 \%)$ in feed. Furthermore, there was significant $(\mathrm{P}<0.05)$ effect of treatments for feed efficiency. The best feed conversion ratio was recorded in group feed with $16.5 \%$ crude protein diet as compared to other groups. These results are supported by AbebeTafa et al. [25] and ErmiasTekletsadik [26], who reported that feed intake and growth performance increased in Arsi-bale lambs provided higher protein level in comparison with low protein ratio. These findings are also agreed with the results of [27]. Keser et al. [28], found that live body weight, average daily gain and FCR were best for lambs fed the $16 \%$ crude protein diet in comparison with lambs fed $10 \%$.

Table 2. Effect of crude protein levels on growth performance of male Pateri goat kids

\begin{tabular}{|l|l|l|l|l|}
\hline \multirow{2}{*}{ Variables } & \multicolumn{4}{|l|}{ Groups of male Pateri kids with crude protein levels } \\
\cline { 2 - 5 } & $\mathbf{A}(\mathbf{1 1 . 5 \%})$ & $\mathbf{B}(\mathbf{1 4 . 5 \%})$ & $\mathbf{C ~ ( 1 6 . 5 \% )}$ & S.E \pm \\
\hline DMI (g/d) & 707.90 & 696.05 & 682.15 & 8.597 \\
\hline ADG (g/d) & $95.05^{\mathrm{b}}$ & $102.61^{\mathrm{ab}}$ & $110.66^{\mathrm{a}}$ & 3.095 \\
\hline FCR & $7.47^{\mathrm{a}}$ & $6.80^{\mathrm{ab}}$ & $6.17^{\mathrm{b}}$ & 0.233 \\
\hline Total weight $(\mathrm{kg})$ & $21.12^{\mathrm{b}}$ & $21.86^{\mathrm{ab}}$ & $22.57^{\mathrm{a}}$ & 0.238 \\
\hline
\end{tabular}

Super script with different letters indicated significant level $(\mathrm{P}<0.05)$. DMI: Dry matter intake; ADG: Average daily gain and FCR: Feed conversion ratio

\section{Nutrient digestibility}

The utilization of crude protein and ether extract in terms of digestibility indicated linearly significant $(\mathrm{P}<0.05)$ difference among the supplemented groups except ADF and NDF (Table 3). The apparent digestibility of crude protein and E.E was higher in $\mathrm{C}$ group. [9], reported that diets supplemented to goats with higher protein levels results in higher values for the digestibility of crude protein and ether extract compared with low protein diet. These findings are well agreed with [29] who found that 12 and $15 \%$ crude protein ratio in feed of goats improved the digestibility of C.P in comparison with $10 \%$ level. Increase level of C.P in diet stimulates the microbial fermentation activity and synthesis of microbial protein.

Table 3. Effect of crude protein levels on digestibility percentage of male Pateri goat kids

\begin{tabular}{|l|l|l|l|l|}
\hline \multirow{2}{*}{ Variables } & \multicolumn{4}{|l|}{ Groups of male Pateri kids with crude protein levels } \\
\cline { 2 - 5 } & $\mathbf{A ~ ( 1 1 . 5 \% )}$ & $\mathbf{B ~ ( 1 4 . 5 \% )}$ & $\mathbf{C ~ ( 1 6 . 5 \% )}$ & S.E \pm \\
\hline C.P & $66.72^{\mathrm{b}}$ & $69.66^{\mathrm{ab}}$ & $73.97^{\mathrm{a}}$ & 1.804 \\
\hline E.E & $56.72^{\mathrm{b}}$ & $59.30^{\mathrm{ab}}$ & $63.07^{\mathrm{a}}$ & 1.545 \\
\hline N.D.F & 55.67 & 57.40 & 58.84 & 1.891 \\
\hline A.D.F & 45.82 & 47.32 & 49.65 & 1.454 \\
\hline
\end{tabular}

Super script with different letters indicated significant level $(\mathrm{P}<0.05)$. C.P: Crude protein; E.E: Ether extract; NDF: Non detergent fiber and ADF: Acid detergent fiber 
Effects of treatments on carcass characteristics are illustrated in Table 4. Analysis of variance showed no-significant $(\mathrm{P}<0.05)$ effect of treatments on carcass weight and dressing percentage but numerical variation were noted. More carcass weight and dressing percentage was recorded in $\mathrm{C}$ group as compared with other treated groups. Dressing percentage is closely interlinked with live body weight at the time of slaughter. Hence, dressing \% increased as live body weight increased at slaughter period $[30,31]$. Regarding the previous research conducted by Titti et al. [8], Rocha et al. [19] and Choi et al. [32], they reported that feed contain more protein ratio did not results in significant influence on carcass yield. Furthermore, Wiese et al. [33] found that high protein level in lambs not increased the carcass weight and dressing \% these findings are harmony with our results.

Table 4. Effect of crude protein levels on carcass weight and dressing percentage of male Pateri goat kids

\begin{tabular}{|l|l|l|l|l|}
\hline \multirow{2}{*}{ Variables } & \multicolumn{4}{|l|}{ Groups of male Pateri kids with crude protein levels } \\
\cline { 2 - 5 } & $\mathbf{A ~ ( 1 1 . 5 \% )}$ & $\mathbf{B}(\mathbf{1 4 . 5 \% )}$ & $\mathbf{C ~ ( 1 6 . 5 \% )}$ & S.E \pm \\
\hline Carcass weight & 11.30 & 11.96 & 12.67 & 0.374 \\
\hline Dressing \% & 53.50 & 54.71 & 56.13 & 1.323 \\
\hline
\end{tabular}

\section{Conclusion}

On the basis of findings of present research it was concluded that, the ideal dietary crude protein level for the better growth, carcass and digestibility percentage is $16.5 \%$ for Pateri male goat kids.

\section{Author's contributions}

Conceived and designed the experiments: SA Pirzado, M Haroon \& M Zakria, Performed the experiments: SA Pirzado, Analyzed the data: M Tariq \& D Hussain, Contributed reagents/ materials/ analysis tools: GA Mughal \& RA Laghari, Wrote the paper: SA Pirzado, IH Laghari, \& F Parveen,

\section{References}

1.Casey NH, Van Niekerk WA \& Webb EC (2003). Goat meat. In: Caballero, B; Trugo, $\mathrm{L}$ and Finglass, $\mathrm{P}$ (Eds.), Encyclopedia of food Sciences and nutrition. (2nd Edn.), London, UK, Academic Press pp: 2937-2944.

2.Matossian de Pardo C (2000). Market studies and good quality products are the key to successful projects. Paper Presented at the Seventh International
Conference on Goats, France. 14th/May. pp: 15-21.

3. Sen AR, Santra A \& Karim SA (2004). Carcass yield, composition and meat qualityattributes of sheep and goat under semiarid conditions. Meat Sci 66: 757-763.

4. McMillin KW \& Brock AP (2005). Production practices and processing for value-added goat meat. J. Anim. Sci 83: 57-68.

5. Shahbabak MS, Rozbahan Y, Shahrbabak MM \& Shahrbabak HM (2006). Effect of different levels of digestible undegradable protein on the fattening performance of Kermani male lambs. J. Anim Nutr. 88(2): 721-723.

6. Nkosi BD, Leeuw KJ, Langa T, Thomas RS (2011). Effects of different dietary inclusion levels of sunflower oil cake on the growth performance of South African Mutton Merino lambs. Res. Opin. Anim. Vet. Sci 1: 330-333.

7. Prieto I, Goetsch AL, Banskalieva V, Camerton M, Puchala R, Sahlu T, Dawson LJ \& Coleman SW (2000). Effects of dietary protein concentration 
on postweaning growth of Boer crossbred and Spanish goat wethers. J. Anim. Sci 78: 2275- 2281.

8. Titi HH, Tabbaa MJ, Amasheh MG, Barakeh F \& Daqamseh B (2000). Comparative performance of Awassi lambs and Black goat kids on different crude protein levels in Jordan. Small Rumin. Res 37: 131-135.

9. Shahjalal M, Bishwas MAA, Tareque AMM \& Dohi H (2000). Growth and carcass characteristics of goats given diets varying protein concentration and feeding level. Asian-Aust. J. Anim. Sci 13: 613-618.

10. Harb M (1994). Sheep Production under Extensive Systems in the Near East: Jordan Pastoral System, a Case Study. FAO, Rome. Kellems, R.O., Church, D.C., 1998. Livestock Feeds and Feeding. Prentice Hall, New Jersey.

11. AOAC (2000). Official methods of analysis. 17th ED. Association of Official Analytical Chemists, Washington, DC.

12. Van Soest PJ, Robertson JB \& Lewis BA (1991). Methods for dietary fiber, neutral detergent fiber, and nonstarch polysaccharides in relation to animal nutrition. J. Dairy Sci 74: 3583-3597.

13. Huston JE, Engdahl GS \& Bales KW (1988). Intake and digestibility in sheep and goats fed three forages with different levels of supplemental protein. Small Rumin. Res 1: 81-92.

14. Cheema AU, Galyean ML, Caton JS \& Freeman AS (1991). Influence of protein levels and naloxone on intake, nitrogen metabolism and digestion kinetics in lambs fed oat hay or barley stra w. Small Rumin. Res 5: 3546.

15. Ahn BH \& Moon YH (1985). Effect of dietary Effect of dietary protein and calcium levels on digestibility, nitrogen balance and some mineral retention in sheep. Kor. J. Anim. Sci 27: 507-514.

16. Choi SH, Kim SW, Park BY, Sang BD, Kim YK, Myung JH \& Hur SN (2005). Effects of dietary crude protein level on growth and meat quality of Korean native goats. J. Anim. Sci. Technol. (Kor.) 45: 783-788.

17. Chobtang $\mathrm{J}$, Intharak $\mathrm{K}$ \& Isuwan $\mathrm{A}$ (2009). Effect of dietary crude protein levels on nutrient digestibility and growth performance of Thai indigenous male goats. Songklanakarin J. Sci. Techn 31: 591-596.

18. Zundt M, Macedo FAF, Martins EL, Mexia AA \& Yamamnoto SM (2002). Desempenho de cordeirosalimentados com diferentesníveisprotéicos. RevistaBrasileira de Zootecnia 31: 1307-1314.

19. Rocha MH, Susin AV, Pires SF \& Mendes CQ (2004). Performance of Santa Ines lambs fed diets of variable crude protein levels. Sci. Agric 61: 141145.

20. Mtenga LA \& Kitaly AJ (1990). Growth performance and carcass characteristics of Tanzanian goats fed Chloris gayana Hay with different levels of protein supplement. Small Rumin. Res 3: 1-8.

22. Jia ZH, Sahlu T, Femandez JM, Hart SP $\&$ Teh TH (1995). Effects of dietary protein level on performance of Angora and cashmere-producing Spanish goats. Small Rumin. Res 16: 113-119.

23. Wildeus S, Luginbuhl JM, Turner KE, Nutall YL \& Collins JR (2007). Growth and carcass characteristics in goat kids fed grass-and alfalfa-hay-based diets with limited concentrate supplementation.

24. Negesse T, Rodehutscord M \& Pfeffer E (2001). The effect of dietary crude protein level on intake, growth, protein retention and utilization of growing 
male Saanen kids. Small Rumin. Res 39: 243-251.

25. Tafa A, Melaku S \& Peters KJ (2010). Supplementation with linseed (Linum usitatissimum) cake and/or wheat bran on feed utilization and carcass characteristics of Arsi-Bale sheep. Tropical animal health and production 42(4): 677-685.

26. Ermias T (2008). The Effect of Supplementation with barely bran, linseed meal and their mixtures on the performance of Arsi-Bale sheep fed a basal diet of faba bean haulms. MSc Thesis. Haramaya University, Ethiopia.

27. Haddad SG, Nasr RE \& Muwalla MM (2001). Optimum dietary crude protein level for finishing Awassi lambs. Small Rumin. Res 39: 41-46.

28. Keser O, Bilal T \& Cankutay H (2008). The effect of different dietary crude protein level on performance and serum immunoglobulin $\mathrm{g}$ in male Kivircik lambs. Bulgarian Journal of Veterinary Medicine 11(1): 49-54.

29. Atti N, Rouissi H \& Mahouachi M (2004). The effect of dietary crude protein level on growth, carcass and meat composition of male goat kids in Tunisia. Small Rumin. Res 54: 89-97.

30.Marinova P, Banskalieva Y, Alexandrov S, Tzvetkova V \& Stanchev H (2001). Carcass composition and meat quality of kids fed sunflower oil supplemented diet. Small Rumin. Res 42: 217-225.

31. Mourad M, Gbanamou G \& Balde LB (2001). Carcass characteristics of West African dwarf goats under extensive system. Small Rumin. Res 42: 81-85.

32. Choi SH, Hwangbo S, Kim SW, Kim YK, Sang BD, Myung JH, Hur SN \& Jo IH (2007). Effects of dietary energy level on growth and meat quality of Korean native goats. J. Anim. Sci. Technol. (Kor.) 49: 509-514.

33. Wiese SC, White CK, Master DG \& Milton JB (2003). The growth performance and carcass attributes of Merino and Poll Doreset $\mathrm{x}$ Merino lambs fed rumen-protected methionine (Smartamine TM-M). Australian J. Agric. Res 54: 507-513. 